J. Clin. Chem. Clin. Biochem.

Vol. 28, 1990, pp. $471-474$

(C) 1990 Walter de Gruyter \& Co. Berlin $\cdot$ New York

\title{
Synthesis and Characterization of a New Substrate of Photinus pyralis Luciferase: 4-Methyl- $D$-luciferin
}

\author{
By Corinne Farace ${ }^{1}$, B. Blanchot ${ }^{2}$, D. Champiat $^{1}$, P. Couble ${ }^{3}$, G. Declercq ${ }^{2}$ and J.-L. Millet ${ }^{4}$ \\ ${ }^{1}$ CEMAGREF, Laboratoire de Biochimie, Lyon, France \\ 2 ESCOM, Paris, France \\ ${ }^{3}$ Université Claude Bernard, UMR CNRS 106, Villeurbanne, France \\ ${ }^{4}$ Prolabo, Paris, France
}

(Received May 22, 1989/January 31, 1990

Summary: A derivative of luciferin, 4-methyl- $D$-luciferin, was synthesized in low yield, and characterized by its ultraviolet and fluorescence spectra. The spectra of luciferin and its derivative are very similar. 4-Methyl$D$-luciferin is a substrate of Photinus pyralis luciferase, and it causes light emission in luminometric assays.

\section{Introduction}

Firefly luciferase catalyses the ATP-dependent oxidative decarboxylation of $D(-)$-luciferin, accompanied by the production of light.

Firefly luciferin, $D(-)-2-\left(6^{\prime}\right.$-hydroxy-2'-benzothiazolyl)-2-thiazoline-4-carboxylic acid was first isolated in pure form from the American firefly Photinus pyralis in 1957 by Bitler \& Mc Elroy (1). Luciferin was subsequently chemically synthesized and characterized by White et al. (2).

Many structural analogues of luciferin have been synthesized $(3-7)$. All are characterized by substitution of the carboxyl group or the phenoxide ion. However, since these two chemical groups are essential for luciferin light emission properties (8), the synthesized derivatives are poor substrates or require post modifications $(7,9)$.

With the aim of constructing luciferin-labelled macromolecules, in which the luciferin moiety is branched through a carbon spacer on carbon 4 , we have investigated whether 4-methyl- $D$-luciferin behaves as a substrate of luciferase. In this paper, we present the protocol for the synthesis of this compound, and describe its physico-chemical properties and its light emission properties during luciferasecatalysed oxidation. It was shown that the methylderivative possesses strong light emission properties, confirming that substitution on carbon 4 is suitable for linking to other biomolecules.

\section{Materials and Methods}

The products used for synthesis of 4-methyl- $D$-luciferin and the solvents for its purification were purchased from Aldrichchimie, France.

D-Luciferin (Photinus pyralis), luciferase (Photinus pyralis; $8 \mathrm{U} / \mathrm{mg}$ ) and ATP were purchased from Boehringer Mannheim, FRG.

\section{Synthesis of 4-methyl-D-luciferin}

This compound was synthesized by a modification of the White \& Mc Capra procedure (1).

4-Methoxy 2-methylaniline is condensed with ethyloxalate to give the oxamate (I). This compound is converted to the thioamide with phosphorus pentasulphide and hydrolysed without isolation to give the thiooxamic acid (II). Oxidation of (II) with alkaline ferricyanide gives the benzothiazole compound (III), which is converted into the amide (IV) by treatment with thionyl chloride, then ammonia. Dehydration with phosphorus oxychloride leads to the nitrile (V). Demethylation of (V) by pyridine hydrochloride gives the phenol (VI). Condensation of (VI) with $D$-cysteine gives a low yield of the required luciferin (VII). 


\section{Spectrometry}

Ultra-violet spectra were made at room temperature using a Uvikon 860 spectrophotometer (Kontron Instrument). Fluorescence spectra were made with a spectrofluorimeter JY 3D (Jobin Yvon) at room temperature. The buffer used in both

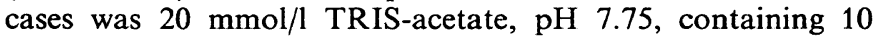
$\mathrm{mmol} / \mathrm{l}$ magnesium acetate.

\section{HPLC chromatography}

We used the following HPLC system: column PROLABO SiC5 $(250 \times 4 \mathrm{~mm})$; flow $0.6 \mathrm{ml} / \mathrm{min}$; wavelength $270 \mathrm{~nm}$. Eluant: $0.05 \mathrm{~mol} / \mathrm{l}$ ammonium acetate $(\mathrm{pH} 7.0)$, methanol, volume fraction 0.52 .

\section{Determination of enzyme activity}

The acticities of luciferin and its derivative as substrates of luciferase were compared according to the modified procedure of Miska \& Geiger (9). The bioluminometer (Clinilumat LB 9502T) was from Berthold Wildbad, FRG. A solution containing $2.5 \mathrm{mg} / \mathrm{l}$ luciferase and $10 \mathrm{mmol} / 1 \mathrm{ATP}$ in $20 \mathrm{mmol} / \mathrm{l} \mathrm{TRIS}-$ acetate, pH $7.75,10 \mathrm{mmol} / 1 \mathrm{Mg}^{2+}, 0.66 \mathrm{mmol} / 1$ EDTA, 0.1 $\mathrm{mmol} / 1$ dithioerythritol, $0.01 \mathrm{~g} / 1 \mathrm{NaN}_{3}$ and $0.1 \mathrm{~g} / 1$ bovine serum albumin, was preincubated at room temperature for 20 minutes. One hundred microlitres $(100 \mu \mathrm{l})$ of this solution were then mixed with the same volume of diluted luciferin or luciferin derivative; light impulses were integrated for 10 seconds at $25^{\circ} \mathrm{C}$.

Each enzyme substrate was assayed four times independently. Triplicate determinations were carried out for each assay and the coefficient of variation was expressed as a percentage of the mean value.

\section{Results and Discussion}

\section{Synthesis of 4-methyl-D-luciferin}

Methyl luciferin was synthesized in 7 steps, each in fairly good yield, except for the last one. They are described on figure 1.
Ethyl-N-(4-methoxy 2-methyl-phenyl)oxamate (I)

Ethyloxalate $(1.5 \mathrm{~mol})$ was heated to $120^{\circ} \mathrm{C}$. Amine $(0.73 \mathrm{~mol})$ was then added and the temperature of the mixture raised to $180^{\circ} \mathrm{C}$ for five minutes. After cooling the mixture in an ice bath, the precipitated solid was collected, then washed with ethanol and ether; m. p. $94{ }^{\circ} \mathrm{C}$; yield $65 \%$.

\section{N-(4-Methoxy 2-methyl-phenyl)thiooxamic acid (II)}

$43 \mathrm{~g}$ of (I) were added to 0.91 of boiling xylene, followed by the addition of $14.5 \mathrm{~g}$ of phosphorus pentasulphide in small portions to the boiling solution. Reflux was continued for 2 hours. After cooling, the mixture was extracted with ten 150 $\mathrm{ml}$ portions of $1 \mathrm{~mol} / \mathrm{l}$ sodium hydroxide. The basic extracts were filtered, cooled to $0{ }^{\circ} \mathrm{C}$ and acidified with concentrated hydrochloric acid $(200 \mathrm{ml})$. The precipitate was collected and washed with water. We used this crude material for the oxidation.

\section{6-Methoxy-4-methyl-benzothiazole 2-carboxylic acid (III)}

Crude (II) was dissolved in $1 \mathrm{~mol} / \mathrm{l}$ sodium hydroxide $(700 \mathrm{ml})$ and oxidized with potassium ferricyanide $(200 \mathrm{~g}$ in $500 \mathrm{ml}$ of water) by slow addition of the thioxamic acid to the ferricyanide solution, keeping the temperature of the mixture below $10^{\circ} \mathrm{C}$. The mixture was filtered and the solid collected. The solid was suspended in water with stirring, and acidified with concentrated hydrochloric acid. A brown solid was precipitated; m. p. $127^{\circ} \mathrm{C}$; yield $66 \%$ (from the oxamate); NMR (in DMSO): 7.65 and $7.2 \mathrm{ppm}$ aromatic protons, $3.9 \mathrm{ppm} \mathrm{OCH}_{3}, 2.7 \mathrm{ppm} \mathrm{OCH}_{3}$.

\section{6-Methoxy-4-methyl-benzothiazole 2-carboxamide (IV)}

$0.117 \mathrm{~mol}$ of (III) and $150 \mathrm{ml}$ of thionyl chloride were refluxed for two hours. The excess thionylchloride was removed and the remaining product was dissolved in $200 \mathrm{ml}$ of methylene chloride. Gaseous ammonia was bubbled through the solution for 4 hours. The precipitate was filtered and washed with water to yield $10 \mathrm{~g}(40 \%)$ of a solid melting at $205.8{ }^{\circ} \mathrm{C}$.

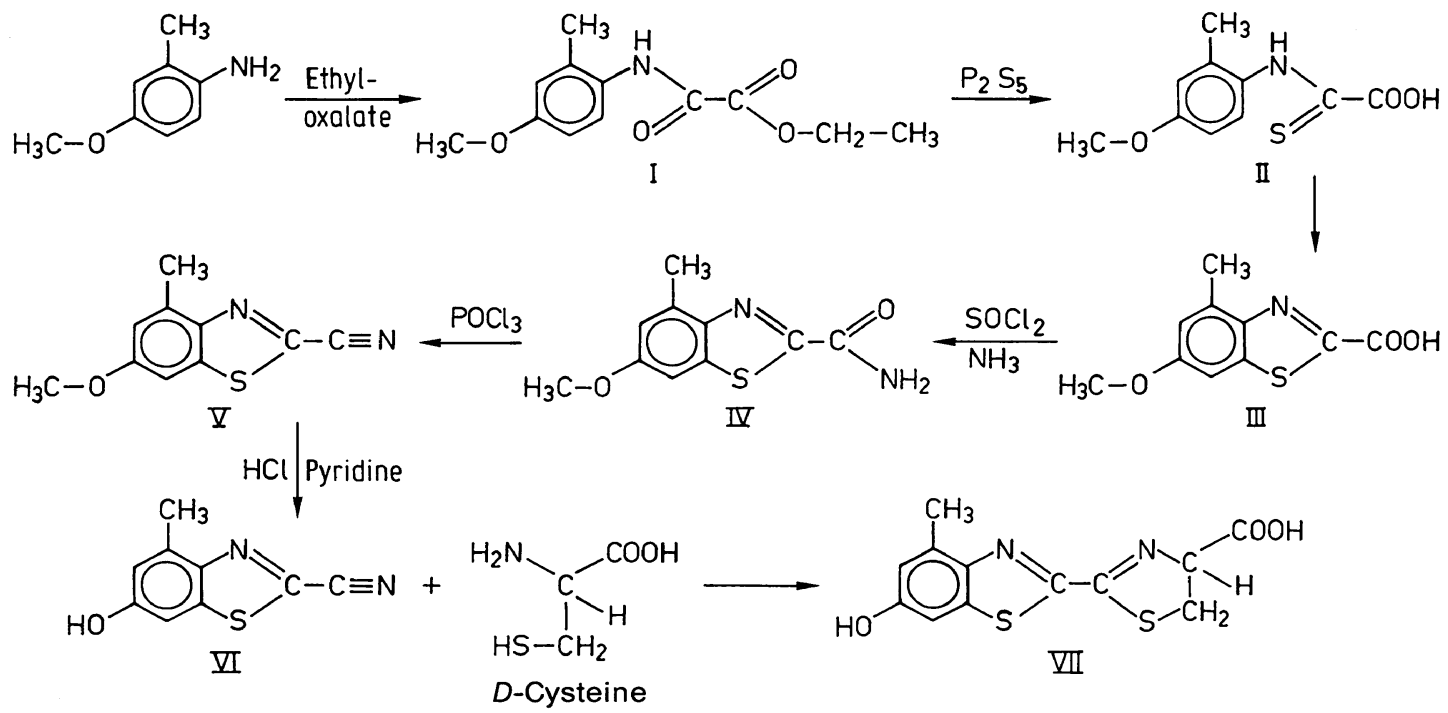

Fig. 1. Reaction scheme for the synthesis of 4-methyl- $D$-luciferin. 


\section{2-Cyano-6-methoxy-4-methyl benzothiazole (V)}

We heated a mixture of $0.022 \mathrm{~mol}$ of $(\mathrm{V})$ with $30 \mathrm{ml}$ of phosphorus oxychloride under reflux, until all the amide had dissolved (ca $15 \mathrm{~min}$ ). The excess phosphorus oxychloride was removed as completely as possible. The residue was cooled, ether added and the solution was decomposed with $10 \mathrm{~g} / \mathrm{l}$ sodium bicarbonate solution. The $\mathrm{pH}$ was adjusted to 6 and the nitrile was extracted with chloroform.

The chloroform solution was washed with water, dried over magnesium sulphate, and the solvent evaporated to give $3 \mathrm{~g}$ of an oily product (yield $67 \%$ ).

\section{2-Cyano-6-hydroxy-4-methyl benzothiazole (VI)}

Pyridine hydrochloride $(20 \mathrm{~g})$ was heated to $220^{\circ} \mathrm{C}$ in an anhydrous atmosphere. Then (V) $(1.5 \mathrm{~g})$ was added in small portions. The mixture was heated with stirring at $220^{\circ} \mathrm{C}$ for an hour. After cooling, the black solution was decomposed with a $100 \mathrm{~g} / 1$ sodium carbonate solution, taking care that the solution did not become strongly alkaline. The solid was then filtered.

For purification, the crude nitrile was dissolved in ethanol and passed through a column of charcoal $(4 \mathrm{~g})$ and celite $(7 \mathrm{~g})$.

Removal of the solvent gave $100 \mathrm{mg}(7 \%)$ of (VI).

NMR $\left(\mathrm{CD}_{3} \mathrm{COCD}_{3}\right) 8.5 \mathrm{ppm} \mathrm{OH}, 7.4$ and $7.1 \mathrm{ppm}$ aromatic protons, $2.7 \mathrm{ppm} \mathrm{CH}_{3}$.

\section{4-Methyl-D-luciferin (VII)}

In a flask of low actinic glass (under a nitrogen atmosphere) $100 \mathrm{mg}$ of $D$-cysteine hydrochloride and $6 \mathrm{ml}$ of $1 \mathrm{~g} / 1$ sodium carbonate solution were mixed with stirring, followed by addition of $100 \mathrm{mg}$ of (VI) in methanol $(5 \mathrm{ml})$. A precipitate formed, then redissolved. After an hour the mixture was acidified with $1 \mathrm{~mol} / 1$ hydrochloric acid and kept at $0{ }^{\circ} \mathrm{C}$ overnight. Rapid filtration gave a pale yellow solid; yield $10 \mathrm{mg}(6.5 \%)$. This product must be protected from light, oxygen and basic conditions.

\section{Chemical characterization}

The luciferin derivative was characterized by ultra-violet and fluorescence spectrophotometry (see spectra in figs. 2 and 3). The UV spectrum of luciferin and its derivative are very similar, indicating that both molecules share the same aromatic structures. Furthermore, as shown in figure 2, we found that luciferin and 4-methyl- $D$-luciferin have the same absorption peak at 266 $\mathrm{nm}$. The fluorometric analysis showed identical peaks of excitation and emission (tab. 1). However, we noted that the intensities for 4-methyl- $D$-luciferin were reduced in comparison with luciferin.

Tab. 1. Fluorescence properties of $D$-luciferin and 4-methyl- $D$ luciferin.

\begin{tabular}{|c|c|c|c|}
\hline $\begin{array}{l}D \text {-Luciferin } \\
\text { derivative }\end{array}$ & Buffer & $\begin{array}{l}\text { Exci- } \\
\text { tation } \\
(\mathrm{nm})\end{array}$ & $\begin{array}{l}\text { Emis- } \\
\text { sion } \\
(\mathrm{nm})\end{array}$ \\
\hline$D$-Luciferin & $\begin{array}{c}20 \mathrm{mmol} / \mathrm{l} \\
\text { Tris acetate } \\
10 \mathrm{mmol} / \mathrm{l} \\
\mathrm{Mg}^{2+}\end{array}$ & 341 & 532 \\
\hline $\begin{array}{l}\text { 4-Methyl- } D \text { - } \\
\text { luciferin }\end{array}$ & $\begin{array}{l}15 \mathrm{mmol}^{1} / 1 \\
\quad \mathrm{NaN}_{3}, \mathrm{pH} 7.75\end{array}$ & 341 & 535 \\
\hline
\end{tabular}

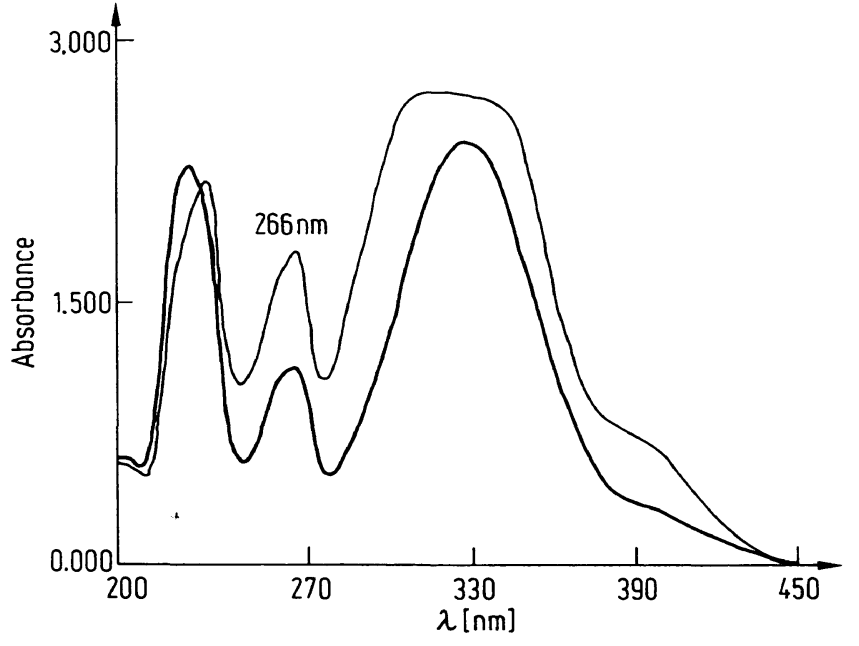

Fig. 2. Ultraviolet spectra of $D$-luciferin (-) and its synthetic derivative (-).
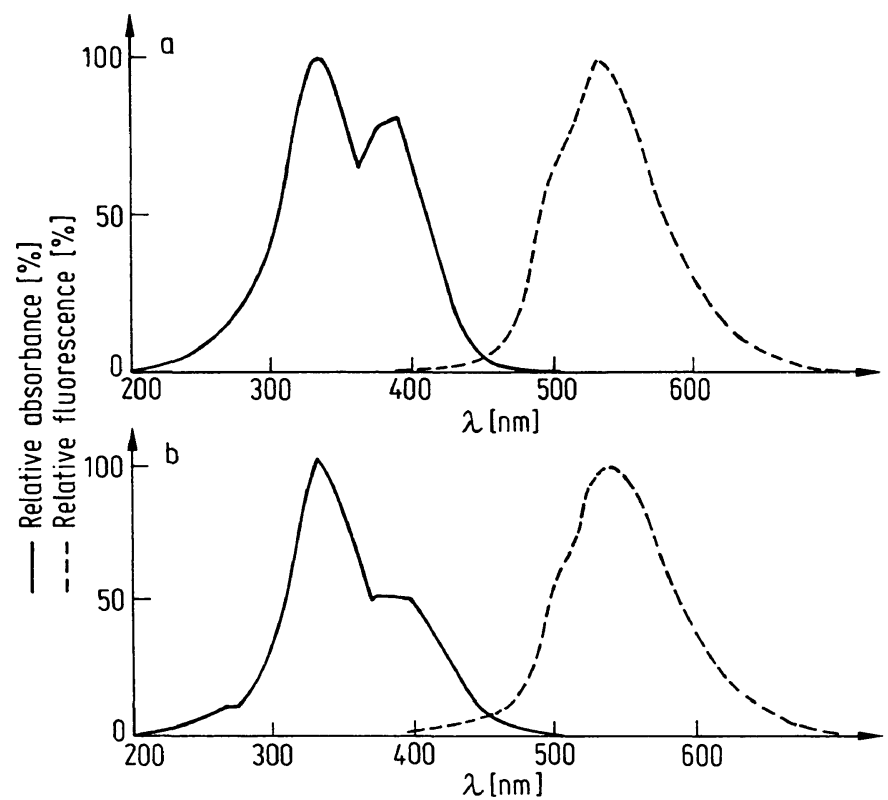

Fig. 3. Fluorescence spectra of $D$-luciferin (a) and its synthetic derivative (b) (left: excitation; right: emission).

In high performance liquid chromatography, the synthesized methylated derivative of luciferin was shown to be homogeneous, with a retention time very close to but greater than that of natural luciferin (data not shown).

\section{Enzymic characterization}

In our procedure, methyl-luciferin was not synthesized by modification of luciferin, but by a total synthesis from appropriate precursors. There is therefore no possibility that luciferin is present, i.e. light production in the enzymic assay cannot be due to or affected by traces of luciferin. The ability of methylluciferin to replace the natural substrate in an enzymic assay was investigated by incubating various amounts of luciferin or methyl-luciferin with fixed amounts of ATP and luciferase. Tensecond light impulse intensities are plotted on figure 4 . This shows that the methylated derivative of luciferin is indeed a substrate of luciferase and that up to 1000 times the background level can be attained at $3.5 \cdot 10^{-5} \mathrm{~mol} / \mathrm{l}$. Also, as for luciferin, 


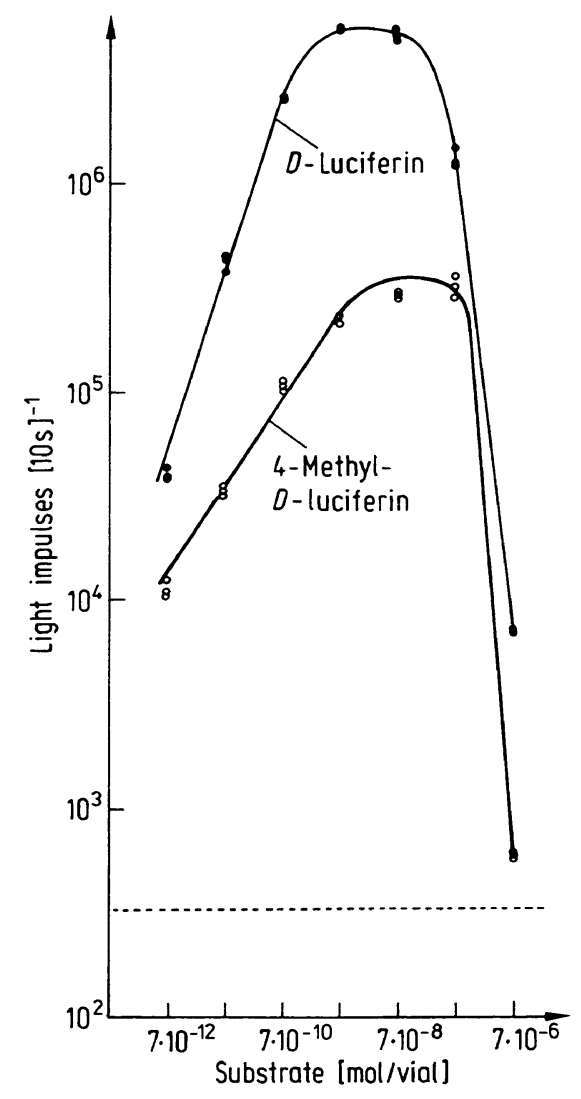

\section{References}

1. Bitler, B. \& Mc Elroy, W. D. (1957) The Preparation and Properties of Crystalline Firefly Luciferin. Arch. Biochem. Biophys. 72, 358-360.

2. White, E. H., Mc Capra, F. \& Mc Elroy, W. D. (1961) The Structure and Synthesis of Firefly Luciferin. J. Am. Chem. Soc. 83, 2402-2403.

3. White, E. H., Mc Capra, F. \& Field, G. F. (1963) The Structure and Synthesis of Firefly Luciferin. J. Am. Chem. Soc. 85, 337-343.

4. White, E. H., Wörther, H., Field, G. F. \& Mc Elroy, W. D. (1965) Analogs of Firefly Luciferin. J. Org. Chem. 30, 2344-2348.

5. White, E. H., Rapaport, E., Hopkins, T. A. \& Seliger, H. H. (1969) Chemi and Bioluminescence of Firefly Luciferin. J. Am. Chem. Soc. 91, 2178-2180.

6. Hopkins, T. A., Seliger, H. H., White, E. H. \& Cass, M. W. (1967) The Chemiluminescence of Firefly Luciferin. A Model for the Bioluminescent Reaction and Identification of the Product Excited State. J. Am. Chem. Soc. 89, 7148. light emission depended on the concentration of the synthetic derivative. Maximum light emission was observed at about the same concentration of both substrates. At high substrate concentration $\left(10^{-2} \mathrm{~mol} / \mathrm{l}\right)$, light emission decreased dramatically. According to De Luca \& Mc Elroy (10) this is due to luciferase inhibition by oxyluciferin, a by-product of the reaction.

Chemical synthesis from ethyloxalate gives a modified derivative without contamination with the natural substrate, which is important for the comparison of the two substrates in the enzymic reaction. As a substrate for light production with luciferase, methyl-luciferin is highly efficient, although it is twenty times less efficient than luciferin. This demonstrates that an additional group in the carbon 4 does not prevent light emission. Substitution of the methyl group on the aromatic ring makes it possible to link luciferin to various molecules. We are now testing the properties of such substrates.

Fig. 4. Determination of $D$-luciferin and its derivative in the luminometric assay (in assay: $10 \mathrm{mmol} / \mathrm{l} \mathrm{ATP}, 0.25 \mu \mathrm{g}$ luciferase). -..- indicates the background (assay without substrate)

7. Miska, W. \& Geiger, R. (1987) Synthesis and Characterization of Luciferin Derivatives for Use in Bioluminescence Enhanced Enzyme Immunoassays: New Ultrasensitive Detection Systems for Enzyme Immunoassays. J. Clin. Chem. Clin. Biochem. 25, 23-50.

8. Gundermann, K. G. \& Mc Capra, F. (1986) Reactivity and Structure Concepts in Organic Chemistry (Afner, K. \& Lehen, J. M., eds.) 23, pp. 151-163, Berlin, Edinburgh, New York, London, Paris, Tokyo.

9. Geiger, R. \& Miska, W. (1987) Bioluminescence Enhanced Enzyme Immunoassay: New Ultrasensitive Systems for Enzyme Immunoassay. J. Clin. Chem. Clin. Biochem. 25, $31-38$.

10. De Luca, M. \& Mc Elroy, W. D. (1978) Purification and Properties of Firefly Luciferase. In: Methods in Enzymology (De Luca, M.A., ed.) 57, 3-15, Academic Press, New York.

\author{
Dr. Jean-Louis Millet \\ PROLABO \\ 12 , rue Pelée \\ BP 369 \\ F-75526 Paris Cedex 11
}

